\title{
The European Convention on Human Rights: an update on Article 3 case law
}

\author{
Martin Curtice
}

\begin{abstract}
SUMMARY
The European Convention on Human Rights and the Human Rights Act 1998 (which enacts most of the Convention rights into UK law) are playing an ever-increasing role in determining the standards of treatment of those detained by the state and hence is of particular importance for those in hospitals, prisons or similar institutions. The European Convention on Human Rights is a 'living instrument' such that judgments emanating from the European Court of Human Rights will continually build upon previous jurisprudence and evolve over time. As Article 3 case law has evolved, its interpretation has broadened to now include a thorough scrutiny of hospital and prison conditions and healthcare provision where people are kept in detention. This article provides an in-depth update on recent Article 3 case law, but more importantly describes new developments in its application in the clinical setting.
\end{abstract}

\section{DECLARATION OF INTEREST}

None.

The importance of knowledge of Article 3 of the European Convention on Human Rights (Council of Europe 2003; enacted in the UK by the Human Rights Act 1998) with regard to psychiatric practice has been described in the pages of this journal and in other reviews of mental health case law (Curtice 2008, 2009). Article 3 is the only absolute Convention right and it states that "No one shall be subjected to torture or to inhuman or degrading treatment or punishment'. It will need to be considered in the clinical setting in complaints arising from conditions of detention, seclusion, control and restraint. Here I review recent judgments from the European Court of Human Rights that demonstrate the application of Article 3, providing an overview of the Article's general principles and demonstrating important developments in its use in the clinical setting.

\section{Kucheruk v. Ukraine (2007)}

The applicant had a diagnosis of schizophrenia and was remanded in custody following charges of hooliganism and theft. He was initially assessed in the medical wing of the prison and then transferred to a psychiatric hospital for 2 weeks to determine his sanity at the time of the alleged offences. He was returned to prison with no treatment despite a forensic psychiatric report that recorded major abnormalities of behaviour, mood and thought processes, and recommended further compulsory in-patient psychiatric assessment and treatment.

After his return to prison the applicant, who was held in an ordinary cell, started to show marked behavioural disturbances. Following an assault by him on one of his cell mates he was transferred to the medical wing. In response to his agitated and erratic behaviour, prison guards felt compelled to forcibly restrain him. They forced him to the floor with the use of rubber truncheons and he was handcuffed and confined to a solitary disciplinary cell. For most of this period he remained handcuffed. He had daily visits from a physician and a psychiatrist but he refused treatment and medication. His behaviour at this time included continued agitation, repeatedly trying to remove the handcuffs, rolling on the floor and banging his head against the wall. He was eventually transferred back to the psychiatric hospital after 11 days spent in the disciplinary cell.

He spent 12 months in the psychiatric hospital and was eventually released from compulsory detention following a recommendation from the psychiatric hospital. Criminal proceedings against him were dropped because of his mental state.

The judgment sequentially analysed four areas of complaint under Article 3 made by the applicant.

\section{Incident of 8 July 2002}

The European Court of Human Rights recalled that in respect of a person deprived of his liberty, recourse to physical force that has not been made strictly necessary by his own conduct diminishes human dignity and is in principle an infringement of Article 3 (Ribitsch v. Austria 1995; Berliński v. Poland 2002).
Martin Curtice is a consultant in old age psychiatry. He obtained a Master of Laws with Distinction in Mental Health Law in 2003 and has an interest in mental health law and the Human Rights Act 1998 He sits on the Royal College of Psychiatrists' Special Committee on Human Rights.

Correspondence Dr Martin Curtice, Consultant in Old Age Psychiatry, Hollyhill Unit, Rubery Lane, Rubery, Birmingham B45 9AY, UK.Email:mirc@ukonline.co.uk 
The applicant maintained that the authorities knew or ought to have known about his deteriorating mental condition and had ample time to consider appropriate measures to prevent his violent outburst on 8 July. Furthermore, despite his erratic behaviour, witnesses commented that he did not constitute any obvious or imminent danger to the prison officers and cellmates. He considered that the use of force against him was unnecessary and excessive, i.e. disproportionate. The government contended that the applicant had been restrained only to the extent made necessary by his own conduct, i.e. the guards had used proportionate force.

In this context the Court found that the use of truncheons was unjustified and amounted to inhuman treatment, thus violating Article 3, i.e. the force used was in essence excessive and disproportionate.

\section{Handcuffing in the disciplinary cell}

The Court recalled that Article 3 enshrines one of the most fundamental values of democratic society - it prohibits in absolute terms torture or inhuman or degrading treatment or punishment, irrespective of the circumstances and the victim's behaviour (Labita v. Italy 2000; Poltoratskiy v. Ukraine 2003; Van der Ven v. the Netherlands 2003). In considering whether a punishment or treatment is degrading within the meaning of Article 3, the Court will also have regard to whether its object is to humiliate and debase the person concerned and whether, as far as the consequences are concerned, it adversely affected their personality in a manner incompatible with Article 3 (Raninen v. Finland 1997). Degrading treatment has also been described as involving treatment such as to arouse feelings of fear, anguish and inferiority capable of humiliating or debasing the victim and possibly breaking their physical or moral resistance (Ireland v. UK 1978; Kudła v. Poland 2000) - the question whether the purpose of the treatment is to humiliate or debase the victim is a further factor to be taken into account, but the absence of any such purpose cannot conclusively rule out a violation of Article 3 (Peers v. Greece 2001; Kalashnikov v. Russia 2002; Ramirez Sanchez v. France 2006).

The Court noted that the use of handcuffs or other instruments of restraint does not normally give rise to an issue under Article 3 where the measure has been imposed in connection with a lawful detention and does not entail the use of force or public exposure exceeding what is reasonably considered necessary (Raninen v. Finland 1997; Mathew v. the Netherlands 2005). Moreover, a measure that is of therapeutic necessity from the point of view of established principles of medicine cannot in principle be regarded as inhuman and degrading - however, a Court must nevertheless satisfy itself that the medical necessity has been convincingly shown to exist (Herczegfalvy $v$. Austria 1992). Furthermore, the manner in which the applicant is subjected to the measure in issue should not go beyond the threshold of a minimum level of severity envisaged by the Court's case law under Article 3 (Nevmerzhitsky v. Ukraine 2005).

The applicant submitted that the period of being constantly handcuffed and the insufficiency of the medical assistance afforded him amounted to a violation of Article 3. The government maintained that the handcuffing was a proportionate and necessary measure in response to the applicant's conduct and the potential threat he posed to himself and others. The Court was struck that having been injured while being restrained and having been observed by medical staff to exhibit self-injurious behaviour even when handcuffed, the applicant was not afforded any medical care for his injuries.

The Court found that the handcuffing of the mentally ill applicant without psychiatric justification or medical treatment for injuries sustained was to be regarded as constituting inhuman and degrading treatment and violated Article 3.

\section{Medical assistance and treatment provided for the applicant}

The applicant submitted that he had not been provided with necessary medical treatment in the course of his detention in prison on two separate periods (4 and 6 weeks respectively). The Court recalled that authorities are under an obligation to protect the health of persons deprived of liberty (Hurtado v. Switzerland 1994) and more importantly the lack of appropriate medical care may amount to treatment contrary to Article 3 (IIhan v. Turkey 2000; Sarban v. Moldova 2005; see also Naumenko v. Ukraine 2004; Farbtuhs v. Latvia 2004). In the case of people with mental illness, the assessment of whether the treatment or punishment concerned is incompatible with the standards of Article 3 must take into consideration their vulnerability and their inability, in some cases, to complain coherently or at all about how they are being affected by any particular treatment (Herczegfalvy v. Austria 1992; Aerts v. Belgium 1998).

The Court concluded that the domestic authorities did not provide appropriate medical treatment to the applicant while he was handcuffed in solitary confinement. It was particularly concerned with the 1-month delay in him being seen by a 
psychiatrist, despite specifically being moved into the psychiatric ward of the prison hospital. Another delay of a month, during which his mental state deteriorated and he assaulted a cellmate, was also of concern following his forensic assessment, which recommended that he be moved to receive treatment in a specialised hospital. The Court found that this level of care could not 'be deemed to be adequate and reasonable medical attention, given the applicant's serious mental condition' and amounted to inhuman and degrading treatment and hence an Article 3 violation.

\section{Effectiveness of the investigation}

The Court recalled that where an individual raises an arguable claim that he or she has been seriously ill-treated by state officials in breach of Article 3, that provision, read in conjunction with the state's general duty under Article 1 of the Convention to 'secure to everyone within their jurisdiction the rights and freedoms defined in ... [the] Convention', requires that there should be an effective official investigation. Such an investigation should be capable of leading to the identification and punishment of those responsible (Assenov and Others $v$. Bulgaria 1998; Labita v. Italy 2000). The minimum standards as to effectiveness also include that the investigation must be independent, impartial and subject to public scrutiny, and that the competent authorities must act with exemplary diligence and promptness (Menesheva v. Russia 2006).

The Court concluded that because of the lack of independence, promptness and public scrutiny on the part of the investigative authorities, the investigation failed to meet the minimum standards of effectiveness and hence there had been a procedural violation of Article 3 .

\section{Final judgment}

The Court held there had been multiple violations of Article 3 in respect of:

- the prison officers' excessive use of force

- the applicant's handcuffing while in detention in the disciplinary cell

- the lack of adequate medical treatment

- the lack of adequate investigation into the applicant's complaints of ill-treatment.

The Court established that the Article 3 violations had occurred while the applicant was deprived of liberty in violation of Article 5 (the right to liberty and security) and, having regard to the comparable case law (Nevmerzhitsky $v$. Ukraine 2005; Khudoyorov v. Russia 2005; Menesheva v. Russia 2006), awarded the applicant, on an 'equitable basis', €20000 in compensation.

\section{Ciorap v. Moldova (2007)}

The applicant worked for a non-governmental organisation specialising in offering legal help to persons deprived of their liberty. He was arrested and charged with a number of serious fraud offences and was subsequently convicted of a number of crimes. He had been diagnosed with 'mosaic schizophrenia'.

\section{Conditions of detention}

The applicant complained that he had to share overcrowded cells with detainees who had infectious diseases such as tuberculosis and about the presence of parasitic insects. He also complained of a lack of proper ventilation and access to daylight (there was no window in his cell and he had electric lights for only 5-6 hours a day) and the rudimentary sanitary conditions allowed no privacy. (See also the Scottish case of Napier [2004] which found that both Article 3 and 8 (the right to respect for private and family life) were violated with regard to the conditions of detention of a remand prisoner, which included 'slopping out' procedures and prompted mass claims by prisoners for compensation totalling millions of pounds.)

The Court commented that the distinction between torture and inhuman or degrading treatment was intended to 'attach a special stigma to deliberate inhuman treatment causing very serious and cruel suffering' (Ireland v. UK 1978). The Court reiterated that to fall within the scope of Article 3, ill-treatment must attain a minimum level of severity and that the assessment of this minimum is relative - it depends on all the circumstances of the case, such as the duration of the treatment, its physical and mental effects and, in some cases, the gender, age and state of health of the victim (Ireland v. UK 1978; see also Papon v. France 2002; Mouisel v. France 2002). The judgment pertinently noted that the state must ensure that:

a person is detained in conditions which are compatible with respect for his human dignity, that the manner and method of the execution of the measure do not subject him to distress or hardship of an intensity exceeding the unavoidable level of suffering inherent in detention and that, given the practical demands of imprisonment, his health and well-being are adequately secured by, among other things, providing him with the requisite medical assistance. (Kudła v. Poland 2000).

More recent case law noted that when assessing conditions of detention, account has to be taken of the cumulative effects of those conditions and the duration of the detention (Ostrovar $v$. Moldova 2005). Unsurprisingly, the Court found 
that the conditions of the applicant's detention had been inhuman, in particular as a result of extreme overcrowding, unsanitary conditions and the poor quality of food, as well as the prolonged period during which the applicant had been detained in such conditions. Article 3 had therefore been violated.

\section{Force-feeding}

The applicant began a hunger-strike as a protest against alleged violations of his rights. Because no prosecutor came to discuss with him the alleged violations for 2 weeks after being imprisoned, he cut his wrists and set fire to himself (the prison psychiatrist considered the applicant had been perfectly aware of the consequences of his actions and that they were a protest against abuses of his rights). The applicant was subsequently force-fed (pursuant to domestic law) on seven occasions when his health was assessed to be deteriorating. His hunger-strike lasted 2 months.

In lodging his force-feeding complaint he described the 'pain and humiliation' caused - he was always handcuffed, even though he never physically resisted force-feeding but simply refused to take food as a form of protest. The prison staff forced him to open his mouth by pulling his hair, gripping his neck and stepping on his feet until he could no longer bear the pain and opened his mouth. His mouth was fixed in an open position by means of a metal mouth-widener. His tongue was pulled out of his mouth with a pair of metal tongs. A hard tube was inserted as far as his stomach and liquidised food was passed through.

The applicant complained that he was forcefed for punitive reasons only and in the absence of any medical necessity. He also complained about the manner in which the force-feeding had been carried out. The government contended the applicant's force-feeding was based on medical need, was ordered and carried out by qualified medical personnel and was authorised by law. The applicant's refusal to eat for 24 days had exposed his life to a real risk and it was the duty of the doctors to protect him (the applicant's suicidal behaviour and being diagnosed with 'mosaic schizophrenia' were additional factors making the restraints necessary according to the government).

The existence of a medical necessity to force-feed the applicant

In Court the government did not produce any evidence of a medical test, or any other investigation, on the basis of which it was decided to initiate the force-feeding. It also observed a paradox in that despite his alleged weakness as a result of his prolonged refusal to take food for 24 days - interrupted by seven force-feedings the applicant's condition was considered to be good enough for him to be allowed to continue his hunger-strike for another 24 days without any apparent need for force-feeding.

The Court opined that in view of the lack of medical evidence that the applicant's life or health were in serious danger (his health had been documented as 'relatively satisfactory' and 'satisfactory', which was 'hardly compatible with a life-threatening condition requiring force-feeding') it could not be said that the authorities acted in the applicant's best interests in force-feeding him. It also concluded that the force-feeding was indeed aimed at discouraging the applicant from continuing his protest rather than being of a therapeutic nature.

The manner of force-feeding the applicant

The Court was 'struck by the manner of the forcefeeding ...', noting that the applicant had requested to be given intravenous drips instead of being forcefed and had even offered his family's assistance in bringing him the necessary equipment. It followed that there was a less intrusive alternative to force-feeding that was not considered, despite the applicant's express request. The Court concluded that the manner of the force-feeding had been unnecessarily painful and humiliating.

\section{The Court's assessment}

The Court noted previous case law had held that:

forced-feeding of a person does involve degrading elements which in certain circumstances may be regarded as prohibited by Article 3. When ... a detained person maintains a hunger-strike this may inevitably lead to a conflict between an individual's right to physical integrity and the State's positive obligation under Article 2 (Right to Life) - a conflict which is not solved by the Convention itself. (X v. Germany 1984)

The Court reiterated that a measure that is of therapeutic necessity from the point of view of established principles of medicine cannot in principle be regarded as inhuman and degrading (Jalloh v. Germany 2006). The same could be said about force-feeding aimed at saving the life of a particular detainee who consciously refuses to take food.

The Court concluded that the applicant's repeated force-feeding was not prompted by valid medical reasons, but rather with the aim of forcing the applicant to stop his protest. Furthermore, it was performed in a manner that unnecessarily exposed him to great physical pain and humiliation that could only be considered as torture, which violated 
Article 3. Deciding on an equitable basis, the Court awarded the applicant €20000 in compensation (for a review of force-feeding and the Human Rights Act 1998, see Curtice 2002).

\section{Dybeku v. Albania (2007)}

This case considered similar Article 3 issues to the two cases mentioned above. It involved the case of a man known to have chronic paranoid schizophrenia. He was found guilty of the illegal possession of explosives and the murder of three people and was sentenced to life imprisonment.

In finding that Article 3 was violated with respect to the inadequacy of detention conditions and inappropriate treatment the applicant received given his poor state of mental health, the judgment provided an in-depth and up-to-date overview of Article 3 general principles that are useful to consider for use in clinical practice (Box 1).

The judgment expounded upon further specific Article 3 principles concerning people in detention with mental health problems. It outlined three particular elements to be considered in relation to the compatibility of a person's health with his stay in detention:

- the medical condition of the prisoner

- the adequacy of the medical assistance and care provided in detention

- the advisability of maintaining the detention measure in view of the state of health of an applicant (Mouisel v. France 2002; Melnik v. Ukraine 2006; Rivière v. France 2006).

Another important Article 3 issue elucidated was, when assessing conditions of detention, account has to be taken of the cumulative effects of those conditions and the duration of the detention, which clearly had a detrimental effect on the applicant's health and well-being (Dougoz v. Greece 2001; Kalashnikov v. Russia 2002). In particular, the Court must have regard to the state of health of the detained person (Assenov and Others v. Bulgaria 1998; Kudła v. Poland 2000; Ramirez Sanchez v. France 2006). The Court considered that the nature, duration and severity of the

B0X 1 Article 3 principles collated from Dybeku v. Albania (2007)

\section{Fundamental value of Article 3}

Article 3 enshrines one of the most fundamental values of democratic society. It prohibits in absolute terms torture or inhuman or degrading treatment or punishment, irrespective of the circumstances and the victim's behaviour.

The need for increased vigilance for Article 3 application for people with mental disorder

The Court considered that feelings of inferiority and powerlessness typical of those with a mental disorder called for increased vigilance in reviewing whether the Convention had been complied with. Here, the Court accepted that the very nature of the applicant's psychological condition made him more vulnerable than the average detainee and that his detention might have exacerbated to a certain extent his feelings of distress, anguish and fear

\section{Protection for incapable patients}

It is for authorities to decide, on the basis of the recognised rules of medical science, on the therapeutic methods to be used to preserve the physical and mental health of patients who are incapable of deciding for themselves. Such patients nevertheless remain under the protection of Article 3.

\section{Minimum level of severity}

III-treatment must attain a minimum level of severity if it is to fall within the scope of Article 3.
The assessment of this minimum level of severity is relative; it depends on all of the circumstances of the case, such as the duration of the treatment, its physical and mental effects and, in some cases, the gender, age and state of health of the victim.

\section{Inhuman treatment}

Treatment has been held to be 'inhuman' because it was premeditated, was applied for hours at a time and caused either actual bodily injury or intense physical and mental suffering.

\section{Degrading treatment}

Treatment has been deemed to be 'degrading' because it was such as to arouse in the victims feelings of fear, anguish and inferiority capable of humiliating and debasing them and possibly breaking their physical or moral resistance.

Whether the purpose of the treatment was to humiliate or debase the victim must also be taken into account, but the absence of any such purpose cannot conclusively rule out a violation of Article 3 .

\section{The level of suffering}

The suffering and humiliation involved must go beyond that inevitable element of suffering or humiliation connected with a given form of legitimate treatment or punishment. Measures depriving persons of their liberty may often involve such an element. Yet it cannot be said that detention in itself raises an issue under Article 3. Nevertheless, under this provision the state must ensure that persons are detained in conditions compatible with respect for their human dignity, that the manner and method of the execution of the measure do not subject them to distress or hardship of an intensity exceeding the unavoidable level of suffering inherent in detention and that, given the practical demands of imprisonment, their health and well-being are adequately secured.

Provision of requisite medical assistance Although Article 3 of the Convention cannot be construed as laying down a general obligation to release detainees on health grounds, it nonetheless imposes an obligation on the state to protect the physical well-being of persons deprived of their liberty, for example by providing them with the requisite medical assistance. A lack of appropriate medical care may amount to treatment contrary to Article 3.

\section{Restrictive regimes}

An important factor, along with the material conditions of detention, is the detention regime. In assessing whether a restrictive regime may amount to treatment contrary to Article 3 in a given case, regard must be had to the particular conditions, the stringency of the regime, its duration, the objective pursued and its effects on the person concerned (Messina v. Italy 1999; Van der Ven v. the Netherlands 2003). 
ill-treatment to which the applicant was subjected and the cumulative negative effects on his health were sufficient to be qualified as inhuman and degrading (Egmez v. Cyprus 2000; Labzov v. Russia 2005; Mayzit v. Russia 2005) and Article 3 was violated.

\section{Standard of medical care}

A very pertinent shift is in the standard of medical care being assessed under Article 3. It is clear that a lack of prompt and requisite care can be sufficient to breach Article 3. Two recent cases have further elucidated this area - in both cases, regular medical attention was provided, but overall it was deemed inadequate and violated Article 3.

\section{Pilcic v. Croatia (2008)}

The first case involved a prisoner who had various undisputed physical ailments. The Court considered the applicant's medical problems, other than kidney stones, had been appropriately treated. Surgery was recommended for his kidney stones. Despite being seen on dozens of occasions for renal symptoms over a 4-year period, no steps were taken to organise surgery. The Court considered that by leaving the applicant to experience considerable occasional pain for a prolonged period of time without a foreseeable prospect of being permanently relieved of his kidney ailment, the prison authorities failed in their obligation to provide the required medical treatment, which constituted inhuman and degrading treatment. (Although this is a medical case, the concept of treatment being inadequate for one disorder in someone who has many disorders that are adequately treated, could easily apply to psychiatric patients.)

\section{Musiał v. Poland (2009)}

The second case involved a young man held on remand and who had schizophrenia. In prison the applicant received regular psychotropic

BOX 2 Evolving aspects of Article 3 case law

\section{Multiple complaints within one Article 3 claim}

Case law demonstrates there can be separate and multiple claims under Article 3 for ill-treatment received (or indeed for treatment not received in the case of physically and mentally unwell people held in detention).

Multiple violations within one Article 3 claim Case law has demonstrated there can be separate and multiple Article 3 violations made from one claim for ill-treatment received.

\section{Proportionality}

There is seemingly a subtle but new shift with regard to the application of the principle of proportionality and Article 3. Because Article 3 is an absolute right - and does not allow for 'degrees' of inhuman or degrading treatment (treatment either is or isn't of a degrading or inhuman or torturous nature) - the principle of proportionality should therefore not apply to the use of Article 3. However, recent judgments with regard to the use of Article 3 and the level of care afforded to people with mental health problems suggest the principle of proportionality is indeed being used in the consideration and assessment of the level of care provided.

\section{Procedural effectiveness}

Another area to consider, particularly for responsible authorities, is the need for effective investigations of Article 3 violations. The Convention expects that there should be an effective official investigation. Such an investigation should be capable of leading to the identification and punishment of those responsible. Minimum standards as to effectiveness also include the requirements that the investigation must be independent, impartial and subject to public scrutiny, and that the competent authorities must act with exemplary diligence and promptness

\section{Conditions of detention}

Courts have examined whether it is compatible with Article 3 for the following categories of persons to be detained in conditions that are not suitable in the light of their physical or mental condition:

- persons with a mental disorder (Kudła v. Poland 2000; Keenan v. UK 2001) or serious illness (Mouisel v. France 2002; Matencio v. France 2004; Sakkopoulos v. Greece 2004)

- the disabled (Price v. UK 2001)

- the elderly (Papon v. France 2002)

- drug addicts experiencing withdrawal symptoms (McGlinchey and Others v. UK 2003).

In particular, the assessment of whether the particular conditions of detention are incompatible with the standards of Article 3 has, in the case of mentally ill persons, to take into consideration their vulnerability and their inability in some cases to complain coherently or at all about how they are being affected by any particular treatment.
Cumulative effects of conditions of detention

When assessing conditions of detention, account has to be taken of the cumulative effects of those conditions and the duration of the detention. In particular, the Court must have regard to the state of health of the detainee.

Level of care for prisoners

Court judgments have pronounced that there are three particular elements to be considered in relation to the compatibility of an applicant's health with his stay in detention:

- the medical condition of the prisoner

- the adequacy of the medical assistance and care provided in detention

- the advisability of maintaining the detention measure in view of the state of health of an applicant.

Deciding compensation on an equitable basis In deciding the amounts of financial compensation for Convention violations, courts will consider and be guided by previous comparable cases and judgments, and the amounts awarded in such judgments. Article 41 of the Convention does not provide for the possibility of awarding damages to anyone save the injured party. 
drugs. Although he had regular access to prison in-house medical staff, he did not remain under regular psychiatric supervision and his access to a psychiatrist had been restricted to emergencies or when he was seen as an out-patient. The Court found that the cumulative effects of the inadequate medical care, and specifically the lack of 'constant and specialised medical supervision', clearly had a detrimental effect on his health and well-being and qualified as inhuman and degrading treatment.

\section{Discussion}

Although the cases discussed are based in the prison setting, the Article 3 principles elucidated can easily be applied to other clinical settings and psychiatric specialties. This review of current case law both re-emphasises core principles in the application of Article 3 and demonstrates newer aspects to be considered in its use that reflect the evolving nature of Convention judgments (Box 2). The areas most pertinent to clinicians are that the standard of medical care and the conditions of detention can violate Article 3 and the principle of proportionality now appears to be being used in assessing the standard of medical care.

With regard to prisoners, the European Committee for the Prevention of Torture is specifically mandated by means of visits to prisons and hospitals to examine the treatment of persons deprived of their liberty with a view to protection of such persons from torture and from inhuman or degrading treatment or punishment. The Committee is unequivocal in its recommendation that all mentally ill prisoners should be cared for and receive treatment in a hospital facility adequately equipped and with qualified staff. The transfer of mentally ill prisoners to an appropriate psychiatric facility should always be considered a high priority (Council of Europe 2004).

In the UK there is further protection for those held in detention with the development of a National Preventive Mechanism as part of the implementation of the United Nations Optional Protocol for the Convention against Torture (OPCAT - United Nations High Commission for Human Rights 2002). This international instrument sets out criteria and safeguards for effective preventive visits by national bodies. The UK National Preventive Mechanism will be comprised of a range of approximately 30 existing inspection organisations and mechanisms that are empowered to enter and inspect places of detention, including inspection without prior notice. This is at least as important as the Deprivation of Liberty Safeguards (Ministry of Justice 2008) introduced in England and Wales in April 2009.
Case law makes it clear that those deprived of their liberty, including those who lack capacity, still remain under the protection of Article 3. It may be interesting to see whether the Deprivation of Liberty Safeguards, which will potentially apply to thousands across the country, pick up as part of the assessment process and reveal over time violations of Article 3 or other Convention rights.

\section{References}

Council of Europe (2003) Convention for the Protection of Human Rights and Fundamental Freedoms as amended by Protocol No. 11. Registry of the European Court of Human Rights September 2003. Council of Europe (http://www.echr.coe.int/nr/rdonlyres/d5cc24a7-dc13-4318-b4575c9014916d7a/0/englishanglais.pdf).

Council of Europe (2004) Report to the Ukrainian Government on the visit to Ukraine carried out by the European Committee for the Prevention of Torture and Inhuman or Degrading Treatment or Punishment (CPT) from 24 November to 6 December 2002. CPT/Inf (2004) 34. Strasbourg, 1 December 2004. Council of Europe (http://www.cpt.coe.int/documents/ ukr/2004-34-inf-eng.htm).

Curtice M (2002) Force-feeding: implications for the Mental Health Act 1983 and the Human Rights Act 1998. Journal of Mental Health 11: $235-42$.

Curtice M (2008) Article 3 of the Human Rights Act 1998: implications for clinical practice. Advances in Psychiatric Treatment 14: 389-97.

Curtice MJR (2009) Medical treatment under Part IV of the Mental Health Act 1983 and the Human Rights Act 1998: review of Article 3 and 8 case law. Psychiatric Bulletin 33: 111-5.

Ministry of Justice (2008) The Mental Capacity Act 2005: Deprivation of Liberty Safeguards. Code of Practice to Supplement the Main Mental Capacity Act 2005 Code of Practice. TSO (The Stationery Office) (http:// www.dh.gov.uk/prod_consum_dh/groups/dh_digitalassets/@dh/@en/ documents/digitalasset/dh_087309.pdf).

Office of the United Nations High Commission for Human Rights (2002) Optional Protocol to the Convention against Torture and other Cruel, Inhuman or Degrading Treatment or Punishment. OHCHR (http://www2. ohchr.org/english/law/cat-one.htm).

Aerts v. Belgium (1998) ECHR Application no. 25357/94 30 July.

Assenov and Others v. Bulgaria (1998) ECHR Application no. 24760/94 28 October.

Berliński v. Poland (2002) Application nos. 27715/95 and 30209/96 20 June.

Ciorap v. Moldova (2007) ECHR Application no. 12066/02 19 June.

Dougoz v. Greece (2001) ECHR Application no. 40907/98 6 March.

Dybeku v. Albania (2007) ECHR Application no. 41153/06 18 December.

Egmez v. Cyprus (2000) ECHR Application no. 30873/96 21 December.

Farbtuhs v. Latvia (2004) ECHR Application no. 4672/02 2 December.

Herczegfalvy v. Austria (1992) 15 EHRR 437.

Hurtado v. Switzerland (1994) ECHR (Merits) Application no. 17549/90 28 January.

IIhan v. Turkey (2000) ECHR Application no. 22277/93 27 June.

Ireland v. UK [1978] 2 EHRR 25.

Jalloh v. Germany (2006) ECHR Application no. 54810/00 11 July

Kalashnikov v. Russia (2002) ECHR Application no. 47095/99 15 July.

Keenan v. UK (2001) ECHR (Merits) Application no. 27229/95 3 April.

Khudoyorov v. Russia (2005) ECHR Application no. 6847/02 8 November.

Kucheruk v. Ukraine (2007) ECHR Application no. 2570/04 6 December.

Kudła v. Poland (2000) ECHR (Merits) Application no. 30210/96 26 October.
MCO answers

1 e 2 b $3 d \quad 4$ e 5 e 
Labita v. Italy (2000) ECHR Application no. 26772/95 6 April.

Labzov v. Russia (2005) ECHR Application no. 62208/00 16 June.

Matencio v. France (2004) ECHR (Merits) Application no. 58749/00 15 January.

Mathew v. the Netherlands (2005) ECHR Application no. 24919/03 29 September.

Mayzit v. Russia (2005) ECHR Application no. 63378/00 20 January.

McGlinchey and Others v. UK (2003) ECHR Application no. 50390/99 29 April.

Melnik v. Ukraine (2006) ECHR Application no. 72286/01 28 March.

Menesheva v. Russia (2006) ECHR Application no. 59261/00 9 March.

Messina v. Italy (1999) ECHR Application no. 25498/94 28 September.

Mouisel v. France (2002) ECHR (Merits) Application no. 67263/01 14 November.

Musiał v. Poland (2009) ECHR Application no. 28300/06 20 January.

Napier, Re Petition for Judicial Review [2004] ScotCS 10026 April.

Naumenko v. Ukraine (2004) ECHR Application no. 42023/98 10 February.
Nevmerzhitsky v. Ukraine (2005) Application no. 54825/00 5 April.

Ostrovar v. Moldova (2005) ECHR Application no. 35207/03 13 September.

Papon v. France (2002) ECHR Application no. 54210/00 25 July. Peers v. Greece (2001) ECHR (Merits) Application no. 28524/95 19 April. Pilcic v. Croatia (2008) ECHR Application no. 33138/06 17 January. Poltoratskiy v. Ukraine (2003) Application no. 38812/97 29 April. Price v. UK(2001) ECHR (Merits) Application no. 33394/96 10 July. Ramirez Sanchez v. France (2006) ECHR Application no. 59450/00 4 July. Raninen v. Finland (1997) ECHR Application no. 20972/92 16 December. Ribitsch v. Austria (1995) ECHR Application no. 18896/91 4 December. Rivière v. France (2006) ECHR Application no. 33834/03 11 July. Sakkopoulos v. Greece (2004) ECHR Application no. 61828/00, 15 January.

Sarban v. Moldova (2005) ECHR Application no. 3456/05 4 October

Van der Ven v. the Netherlands (2003) ECHR Application no. 50901/99 4 May.

Xv. Germany (1984) 7 EHRR 152

\section{MCOs}

Select the single best option for each question stem

\section{With regard to Article 3 :}

a it prohibits in qualified terms torture or inhuman or degrading treatment or punishment, irrespective of the circumstances and the victim's behaviour

b in considering whether a treatment is inhuman, regard will be had as to whether the object is to humiliate and debase the person concerned and whether, as far as the consequences are concerned, it adversely affected their personality

c the question of whether the purpose of a treatment is to humiliate or debase the victim is a factor to be taken into account - the absence of any such purpose will conclusively rule out a violation of Article 3

d inhuman treatment has also been described as involving treatment such as to arouse feelings of fear, anguish and inferiority capable of humiliating or debasing the victim and possibly breaking their physical or moral resistance

e the distinction between torture and inhuman or degrading treatment was intended to attach a special stigma to deliberate inhuman treatment causing very serious and cruel suffering.

\section{Regarding treatment issues relating to} Article 3:

a the use of handcuffs or other instruments of restraint will normally give rise to an issue under Article 3

b when considering the use of force-feeding that is aimed at saving the life of a detainee who consciously refuses to take food, medical necessity must be convincingly shown to exist

c a measure that is of therapeutic necessity from the point of view of established principles of medicine may in principle be regarded as inhuman and degrading

$\mathrm{d}$ a court need not satisfy itself that therapeutic necessity has been convincingly shown to exist

e to fall within the scope of Article 3 , ill-treatment must attain a minimum level of severity and the assessment of this minimum is relative and depends on only some of the circumstances of the case.

3 With regard to persons deprived of their liberty (in either prison or hospital):

a recourse to physical force that has not been made strictly necessary and diminishes human dignity is not in principle an infringement of Article 3

b authorities are not obligated to protect the health of persons deprived of liberty

c in the case of mentally ill persons the assessment of whether treatment is incompatible with Article 3 need not take into consideration their vulnerability

$d$ in the case of mentally ill persons the assessment of whether treatment is incompatible with Article 3 must take into consideration their potential inability to complain coherently, or at all, about how they are being affected by any particular treatment

e the adequacy of medical care provided to those in detention does not need to be considered in relation to a person's health needs.
4 It is true that:

a when assessing conditions of detention, account need not be taken of the cumulative effects of those conditions upon the health and well-being of detained persons

b when awarding financial compensation for Convention, violations courts do not make awards on an equitable basis

c the Convention provides for the possibility of awarding damages to others as well as the injured party

d Court judgments do not allow for separate and multiple complaints within one Article 3 claim for ill-treatment received

e there may be separate and multiple violations of Article 3 within one claim for ill-treatment received.

5 Where an individual raises a claim that they have been seriously ill-treated in breach of Article 3, the Convention requires that there should be an effective official investigation. The minimum standards as to effectiveness include that:

a the investigation need not be capable of leading to the identification and punishment of those responsible

b the investigation may be independent

c the investigation may be impartial

d the investigation may be subject to public scrutiny

e the authorities are expected to act with exemplary diligence and promptness. 